\title{
Coastal Resources Potential in Seririt District, Buleleng Regency
}

\author{
Ahmad Rinaldi ${ }^{1}$, I Putu Ananda Citra ${ }^{2}$ \\ \{arinaldi073@gmail.com ${ }^{1}$, ananda.citra@undiksha.ac.id² ${ }^{2}$, \\ Universitas Pendidikan Ganesha, Indonesia ${ }^{12}$
}

\begin{abstract}
This research was conducted in the coastal area of Seririt District with the aim of 1) Describing the potential of coastal resources in each of the Coastal Villages in Seririt District. The method used in this research is interview and observation. Sampling using purposive sampling technique, because this research is related to the potential of coastal resources and coastal areas, so that will be purposive and used as samples are fishermen who are coastal communities. The samples used in this study for interviews were fishermen and those who were observed were the coastal areas of Seririt District. The data taken in this study is the potential of coastal resources in the Seririt District. The data analysis used in this research is a technical descriptive qualitative analysis. The results showed: 1) coastal resources in each Coastal Village in Seririt District include: (1) biological resources, namely: fisheries potential, coral reefs, and turtles, (2) nonbiological resources, namely: sand and seawater, (3) artificial resources, namely: canoes, canoe engines, and fishing equipment, (4) environmental service resources, namely: marine tourism (canoeing), diving or snorkeling, turtle release attractions, and dolphin attractions.
\end{abstract}

Keywords: Coastal Areas; Coastal Resources; Potential.

\section{Introduction}

The coastal area is an interface between sea and land areas that influence and are influenced by one another, both biogeophysical and socio-economically [1]. Coastal areas also have a strategic meaning because they are transitional areas between terrestrial and marine ecosystems, and have very rich potential for natural resources and environmental services [2]. The island of Bali is one of the islands where most of its territory is a coastal area. The coastal area on the island of Bali has been utilized with various activities, one of which is tourism, both the coastal areas of South Bali and North Bali. However, there is a gap in tourism development in Bali Province, namely between northern Bali and southern Bali. The rapid development, especially beach tourism in southern Bali, such as Kuta Beach and Sanur, almost does not occur on the coast of Buleleng [3].

Buleleng Regency is one of the regencies in the northern region of Bali Province which is known for its natural tourism objects. Buleleng Regency has a land area of 136,588 hectares or $24.25 \%$ of the total area of Bali Province and consists of 9 districts. Also, Buleleng Regency is one of the regencies in Bali which has the longest coastline among other districts, 
with a coastline length of $157.05 \mathrm{~km}$ [4]. The coastline in Buleleng Regency stretches from the east (Tejakula District) to the west (Gerokgak District). Of the 9 sub-districts in Buleleng Regency, 7 sub-districts are coastal areas. Many marine tourism objects have developed in Buleleng Regency. However, on the other hand, there are other districts whose coastal areas are underutilized and developed. One of them is Seririt District, although the development of coastal tourism only develops in western and central Buleleng and Seririt District is included in this part, the development of its coastal area, especially for coastal tourism, is not like Gerokgak District and Buleleng District which are part of western and central Buleleng.

Seririt District is a district that has an area of $111.78 \mathrm{~km}^{2}$ and is the fourth sub-district that has the longest beach length in Buleleng Regency with a beach length of $11.61 \mathrm{~km}$. It is not only the length of the beach that is fourth in the Buleleng Regency but also the number of fishermen. The number of fishermen in the Seririt District is 597 fishermen [4]. Although Seririt District ranks fourth based on the length of beaches in the Buleleng Regency after Gerokgak, Tejakula, and Buleleng, the development of coastal areas in the Seririt District is not that developed compared to the 3 sub-districts. So far, tourists who visit the Buleleng Regency only visit districts that have tourist attractions that are of interest to the tourists themselves. Seririt sub-district is the only sub-district in a coastal area where there are no tourist visits. The following is a table of tourist visits in the Buleleng Regency in each district.

Table 1. Tourist Visits in Buleleng Regency in 2018

\begin{tabular}{|c|c|c|c|c|c|}
\hline No. & Sub-district & Object Name & Domestic & Abroad & Amount \\
\hline 1. & Gerokgak & $\begin{array}{c}\text { Air panas } \\
\text { banyuwedang, Pura } \\
\text { Pulaki, makam } \\
\text { jayaprana, } \\
\text { pemuteran, TNBB }\end{array}$ & 208,703 & 10,355 & 219,058 \\
\hline 2. & Seririt & - & - & - & - \\
\hline 3. & Banjar & $\begin{array}{l}\text { Air terjun munduk, } \\
\text { danau tamblingan, } \\
\text { air panas banjar, } \\
\text { wihara banjar }\end{array}$ & 58,447 & 134,023 & 192,470 \\
\hline 4. & Busungbiu & - & - & - & - \\
\hline 5. & Buleleng & $\begin{array}{c}\text { Lovina, ex } \\
\text { pelabuhan buleleng, } \\
\text { museum buleleng, } \\
\text { gedong kertya, } \\
\text { karang upit labuhan } \\
\text { aji }\end{array}$ & 84,380 & 43,742 & 128,122 \\
\hline 6. & Sukasada & $\begin{array}{c}\text { Danau buyan, air } \\
\text { terjun gitgit }\end{array}$ & 12,329 & 27,264 & 39,593 \\
\hline 7. & Sawan & $\begin{array}{l}\text { Air terjun sekumpul, } \\
\text { pura beji }\end{array}$ & 8,602 & 57,134 & 65,736 \\
\hline 8. & Kubutambahan & $\begin{array}{l}\text { Air sanih, pura } \\
\text { medowe karang }\end{array}$ & 9,931 & 7,981 & 17,932 \\
\hline 9. & Tejakula & Air terjun les & 898 & 2,862 & 3,760 \\
\hline \multicolumn{3}{|c|}{ Jumlah } & 383,290 & 283,361 & 666,671 \\
\hline
\end{tabular}

Sumber: [5] 
Tourist visits in Buleleng Regency occur in gaps between sub-districts in western and central parts of Buleleng. The discrepancy occurs, namely the unequal number of visits to subdistricts including in the western and central parts of Buleleng, namely in Gerokgak District 219.058, Banjar District 192.470, Buleleng District 128,122, while in Seririt District there are none and among the lowest along with Busungbiu District among tourist attraction visits is in Buleleng Regency [5]. This could be one of the problems where the tourist attraction in Seririt District is still lacking, especially for marine tourism, so it requires a strategy to develop coastal areas.

Lack of management and development in the coastal area of Seririt District is a problem that must be resolved by the Seririt District government in particular, especially since the Seririt District ranks fourth in the length of the coast and the number of fishermen in Buleleng Regency and has 9 coastal villages. Therefore, managing and developing coastal areas is very important because coastal areas are very potential areas to be developed in various fields, such as tourism. This can be proven by the potential for abundant coastal resources, such as biological resources, non-biological resources, artificial resources, and environmental services. Strong and sustainable regional economic development is an effective collaboration between the use of existing resources, the community and the government. One of the optimal utilization of local resources is to develop these resources [6].

These potentials must be managed and utilized properly by the government so that coastal areas can develop. However, in Seririt Subdistrict there is still no data that provides information on the potential of coastal resources in each coastal village. Does not require the possibility that every one coastal village has more than one potential coastal resource. Based on the above background, it is interesting to research the potential of coastal resources in each coastal village in Seririt District. This study aims to describe the potential of coastal resources in each Coastal Village. So that later this research will produce data about the potentials owned by the Coastal Village in Seririt District.

\section{Method}

The location in this study is in the coastal area of Seririt District which includes coastal villages. For more details regarding the research location, it can be seen in Figure 1. as follows. 


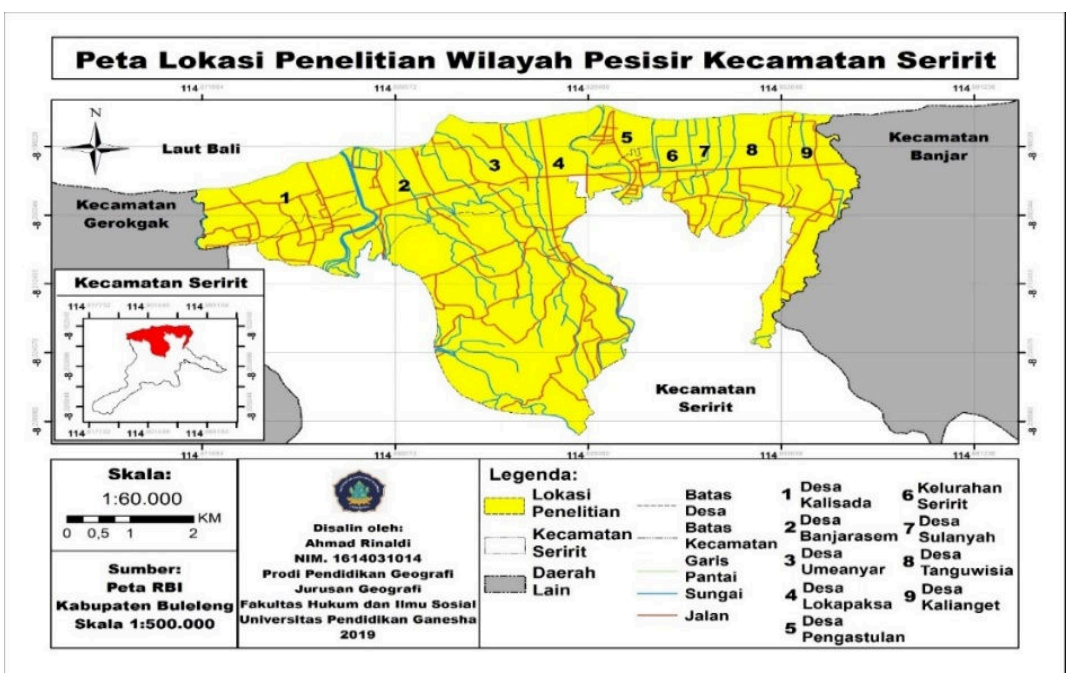

Figure 1. Map of the Research Location

The sampling technique in this study was using a purposive sampling technique. The population used in sampling is the number of fishermen and the determination of the key informants in this study included the Village Head, Bendesa Adat, Community Leaders, Fishermen and the Head of the Fishermen Group in each village. The data collection techniques used in this study were observation and interviews using tools such as observation sheets and questionnaires. This type of reasearch is descriptive qualitative and the variables used are coastal areas and potential of coastal resources which include biological resources, non-biological resources, artificial resources, and environmental services of each Coastal Village in Seririt District.

\section{Result and Discussion}

Coastal resources are a source of income and liverlihood for the community, especially in coastal areas. The importance of coastal resources so that management must integrated [7]: [8]. Potential coastal resources in Seririt District are very diverse and various. The potential coastal resources in Seririt District are as follows.

\section{Biological Resources}

Most of the Coastal Villages in Seririt District have biological resources in the form of fish and coral reefs, but their development is not optimal. Fish are usually sold to markets, collectors, and online. If you get a little, then the fish is consumed personally and sold alone, but if a lot of it is only sold to collectors, markets, or online. Seaweed is also being developed, precisely in Kalianget Village. The seaweed is usually sold online for 80 a pack. 


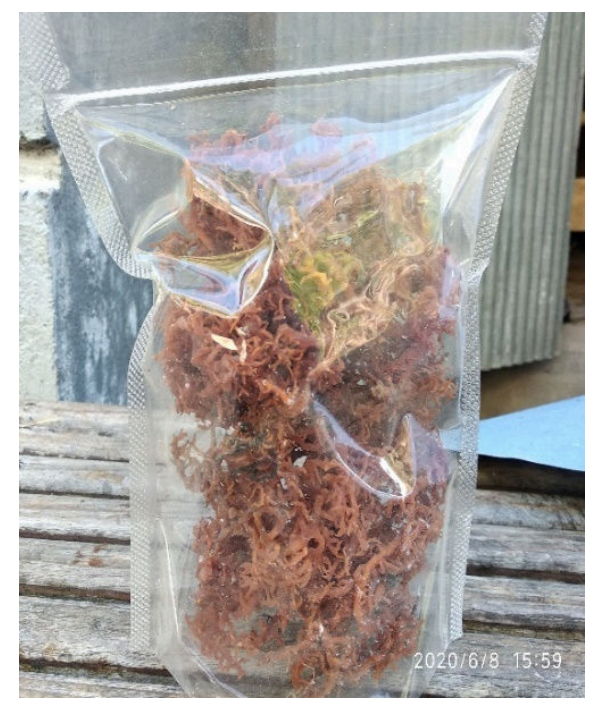

Figure 2. Seaweed that has been wrapped in Kalianget Village

Umeanyar Village is the only Coastal Village in Seririt District which has a lot of biological resources, namely fish, coral reefs, turtles, and seagrass beds. The type of coral reef has been researched, namely ginger coral and it has been developed for tourism, namely diving and snorkeling.

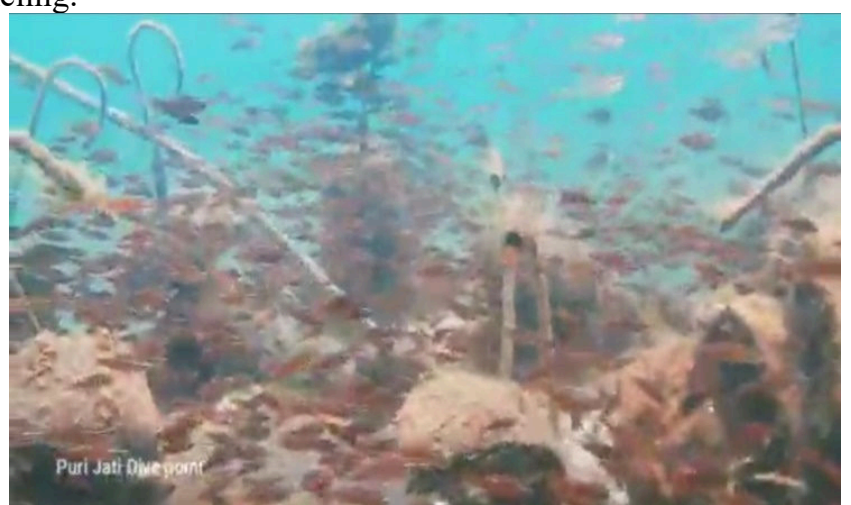

Figure 3. Artificial Coral Reefs in Umeanyar Village

Besides, there are also artificial coral reefs in collaboration with restaurant owners in this village, namely Nalika and the D3 Department of Marine and Fisheries Cultivation, Ganesha University of Education. For the seagrass field itself, it has not been developed, and what kind has not been studied. For turtles, according to the Chairman of POKMASWAS, Mr. I Gusti Bagus Cakra Wijaya, he said that in January 2020190 turtles had been released and 8 more were in captivity to be treated and conserved. 


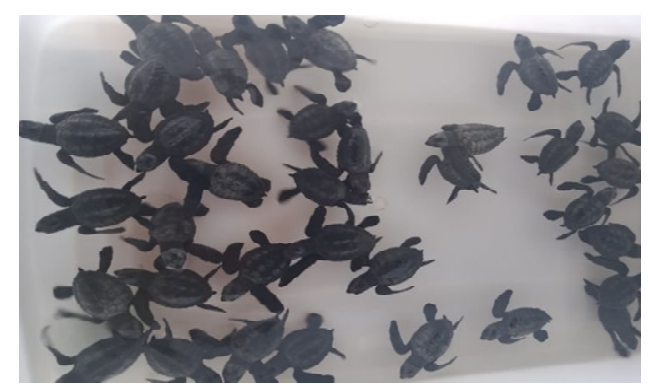

Figure 4. Turtles in the Captivity of Umeanyar Village

The biological resources in Umeanyar Village are only seagrass beds that have not been developed yet because they are still in the research stage of their species. The coral reefs in Umeanyar Village have been researched and the species found are ginger coral and there are also artificial coral reefs, while the turtles in Umeanyar Village are conserved before returning to the sea. The results of this study are in line with research conducted by [9] which examines the identification of potential and mapping of coastal resources in small islands and marine Natuna District, Riau Islands Province. The results of his research show that in the small islands and seas of Natuna Regency, there are many coral reefs with fringing reefs that live along the coast.

\section{Non- Biological Resources}

Non-biological resources based on research results in all coastal villages in Seririt District are the same, namely, there is only sand and seawater, while for the same development, nothing has been developed. The problem with the non-development of nonliving resources in this village is that there is no skill training for processing, there is no expert in the field who processes and develops these resources, there is no management method, no processing system, and equipment. The results of this study are in line with the research [10] regarding coastal resource management strategies in Buleleng Regency. The results showed that Seririt District did not have or did not have developed non-biological resources. The subdistrict that is developing its non-biological resource potential is Tejakula District.

\section{Artificial Resources}

Almost all of the artificial resources in each of the Coastal Villages in Seririt District are almost all the same, namely sampan/boats, sampan/boat engines with a power of 5-15 pk, and fishing equipment.
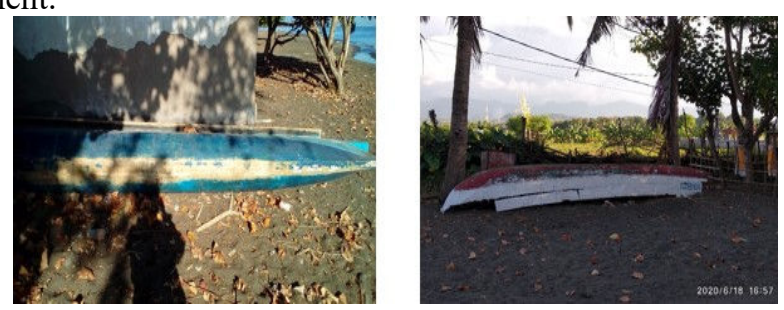

Figure 5. Damaged Artificial Resources in Lokapaksa Village

But the special artificial resources of Lokapaksa Village are now being neglected because the fishermen groups are no longer active and the fishermen have switched professions in the village, while Sulanyah Village does not have artificial resources because 
there are no fishermen or fishermen groups. The results of this study are in line with research [11] who researched the empowerment of the Silo Baru Village fishing community through the Tangguh Coastal Village Management Program (PDPT). The results showed the problems in Silo Baru Village, namely the low level of welfare of the coastal community, low quality of human resources, the absence of spatial planning for coastal areas, the inadequate management of capture fisheries and aquaculture, and the inadequate management of marine tourism potential and attractions so that the implementation of the PDPT program in Silo Village Only then can improve existing conditions and problems.

\section{Environmental Service Resources}

Enviromental service resources in Seririt District are only found in Tangguwisia Village and Umeanyar Village which have implemented tourism villages.

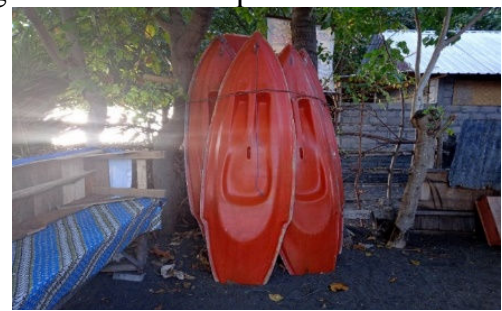

Figure 6. Canoes rented to visitors in Tangguwisia Village

Based on Figure 6. It can be seen that on the coast of Tangguwisia Village canoes are rented out to the public. Usually, visitors who come and rent a canoe in the afternoon. Besides, there are also seeing dolphin. The tourism supporting facilities and infrastructure in this village are villas, 3 boats to see dolphins, and 4 canoes. Umeanyar Village is the only village in Seririt District that applies a Tourism Village. This village has marine tourism such as diving or snorkeling, canoeing, seeing dolphins and turtle release. There are also many tourist support facilities in Umeanyar Village, such as villas, hotels, and restaurants. The results of this study are in line with [10] regarding coastal resource management strategies in Buleleng Regency. The results showed that the types of marine tourism services or environmental service resources found in the Buleleng Regency were observing dolphin attractions, fishing, diving, and snorkeling. The results of this study are in line with [12] regarding coastal resource management strategies in Pemuteran Village. The results showed that the types of marine tourism services or environmental service resources found in the Pemuteran Village were fishing, diving, and snorkeling.

\section{Conclusion}

Based on the results and discussion that has been described regarding the potential of coastal resources in each Coastal Village in Seririt District the following conclusions are obtained. (1) The potential of coastal resources in the coastal areas in the Seririt District is generally diverse, such as fish, coral reefs, seaweed, seagrass beds, turtles, sand, seawater, canoes, canoe engines, fishing equipment, marine tourism, and tourism facilities (villas, hotels, and restaurants). Most of the coastal villages in the Seririt sub-district only develop biological resources, especially fish. However, development is not optimal. Fishermen are only just catching and marketing them. (2) Coastal resource potential that has not been developed at all in the coastal area of Seririt District is non-biological resources. (3) Umeanyar 
Village is the only Coastal Village in Seririt District which has a lot of biological resources, marine tourism and already has many tourism support facilities.

The Impact of this a research is that the community knows potential coastal resources in their village, village officials can also know it so they can develop this potential and the potential coastal resources that were previously unknown can now be known. The recommendation given is that the community pays more attention to coastal areas, especially the potential coastal resources and the government is advised to collaborate with investors to develop the potential coastal resources.

\section{References}

[1] Christiawan, P. I., \& Budiarta, I. G. (2017). Slum Entities in Coastal Areas. Journal of Social Sciences and Humanities, 6(2).

[2] Sutrisno, E. (2014). Implementation of Coastal Resourece Management Based on Integrated Coastal Area Management for Fishermen Welfare (Study in Rural Fishermen Cangkol, Lemahwungkuk Sub-district, Lemahwungkuk District, Cirebon City). Journal of Law Dynamic, 14(1), 1-12.

[3] Citra, I. P. A. (2017). Community Empowerment Strategy for Developing Ecotourism in Coastal Areas in Buleleng Regency. Journal of Social Sciences and Humanities, $6(1), 31-41$.

[4] The Fisheries Office Buleleng Regency. (2019). https://bulelengkab.go.id/assets/instansikab/126/bankdata/buku-data-statistik-tentangrekapitulasi-produksi-perikanan-kabupaten-buleleng-2018-24.pdf.

[5] The Culture and Tourism Office of Buleleng Regency. (2018). https://dispar.bulelengkab.go.id/bankdata/ buku-statistik-penanaman-modal-danpariwisata-daerah-2018-67.

[6] Satria, D. (2009). The Strategy Ecotourism Development Based on Local Economy in the Context of Poverty Alleviation Programs in Malang Regency. Journal of Applied Economics, 3(1), 37-47.

[7] Utojo, U. Mansyur, A. Mustafa, A. Hasnawi, H. Tangko, A. M. (2016). Selection of Enviromentally Friendly Fish, Seaweed and Pearl Oyster Farming Location in the Togean Island, Central Sulawesi. Journal of Aquaculture Research, 2(3), 303.

[8] Aris, M. Fahrudin, A. Riani, E. Mustaqim, E. (2020). Sustainability Analysis of the Marine Recreational Park (MRP) Management in Weh Island Based on Local Custom are Law of the Sea. Journal of Human and Enviroment, 25(1), 25.

[9] Pigawati, B. (2005). Identification of Potential and Mapping of Coastal Resources in Small Islands and the Sea Natuna Regency, Riau Islands Province. Journal of UNDIP, 10(4), 110-120.

[10] Citra, I. P. A. (2018). Coastal Resource Management Strategy in Buleleng Regency. Journal of Social Sciences and Humanities, 4(2), 154-160.

[11] Sitompul, N. R. (2015). Empowerment of the Fishing Community in Silo Baru Village Through Program Pengelolaan Desa Pesisir Tangguh (PDPT). Journal of Administration Sciences, 12(2), 267-288.

[12] Putri, L. N. P. T. I, \& Citra, I. P. A. (2018) Coastal Resource Management Strategy in Pemuteran Ville Gerokgak District Buleleng Regency. Journal of Geography Education Undiksha, 6(1), 12-21. 